\title{
Den danske kongemagt ved vikingetidens begyndelse
}

\section{Af $H$. $V$. Gregersen}

I løbet af de sidste ti-femten år er vor viden om Danevirke-voldene blevet ganske betydeligt udvidet, og den dendrokronologiske datering til året 737 af Nordvolden (og dermed af den ældste del af Hovedvolden) har - populært sagt - gjort vor Danmarkshistorie henved hundrede år ældre. Udgravningsresultaterne i Slesvig/Hedeby og fundet af vikingetidens Ribe har ligeledes bidraget til at skubbe vort lands historie tilbage til begyndelsen af 700-årene, mens det ellers i mange år har været almindeligt at betragte de bedrifter, som de Frankiske Rigsannaler lader kong Godfred og hans mænd udføre, som en art begyndelse på den egentlige Danmarks-historie.

På lignende vis må den tidlige datering af Danevirke og af det ældste Ribe og Slesvig/Hedeby helt naturligt fore til en overvejelse af, hvor berettiget det kan være at lade vikingetiden begynde ved år 800 eller som det oftest sker - med plyndringen af klosteret Lindisfarne på Holy Island i det nordøstlige England $\mathrm{i}$ året 793. ${ }^{1}$ Ingen kan være i tvivl om, at vikingetogene ud over havet på det allernøjeste hang sammen med en udvikling inden for skibsbyggeriet, der har gjort nordboerne - snart kaldt danskerne, snart normannerne eller vikingerne - til havets beherskere. Hvornår denne søstærke skibstype er opstået, kan kun besvares ved hjælp af arkæologiske fund. En del af fundene, f.eks. af skibene fra Kvalsund i Norge og Äskekärr ved Göta älv, samt skibene på de gotlandske billedsten, tyder på, at overgangen til et kølbærende skib med en skrogkonstruktion, der tillader brug af sejl, allerede har fundet sted i 700-årene; men indtil videre er Oseberg-skibet fra begyndelsen af 800-årene det ældste, helt sikre sejlførende skib, som vi har kendskab til.

Inden skibene var blevet således udviklede, at de tillod sejlads ud over havet, var det simpelthen nødvendigt for de søfarende at følge en kystlinje, og selv efter skibenes fortsatte forbedring forblev den kystnære sejlads almindelig århundred efter århundred. ${ }^{2}$

Med udgangspunkt i de store arkæologiske landvindinger inden for det sønderjyske område og sammenlagt med den kendsgerning, at alle 
skriftlige kilder fra tiden før år 800 peger på det sønderjyske område, når der er tale om kontakt med det danske folk, må der tillægges sejladsen langs med Nordsøens sydkyst en ganske særlig betydning. Lad os derfor se på de begivenheder, der i så tidlig tid er knyttet til dette farvand og denne kyst.

Omtalen hos Gregor af Tours af en dansk konge Hugleik (Chochilaicus) som leder af et krigstogt til den del af "Gallien«, der idag må opfattes som den nederlandske kyst, foretaget så tidligt som i året 515, kan tages som et vidnesbyrd om, at der allerede dengang har eksisteret et dansk rige under en konge. Hvor stort dette riges omfang har været, kan der naturligvis kun gisnes om; men udbredelsen af bynavne med endelsen -lev, dækkende det historiske Danmark, samt egnene inde bag ved de skånske landsdele ${ }^{3}$, synes at pege på, at der inden for dette område har eksisteret en folkelig samhørighed - uden at dette naturligvis behøver at indebære, at hele dette område så tidligt har udgjort en rigsenhed.

Fra 500-årene, mere bestemt fra omkring 565, omtales danskerne også $i$ en anden frankisk kilde, nemlig i et hyldestdigt af biskoppen af Poitiers, Venantius Fortunatus, hvori Frankerrigets herskere prises for deres kampe mod danskerne, og inden udgangen af samme århundrede nævnes et fælles dansk-sachsisk angreb på Vestfrisland, Nederlandenes nuværende nordkyst.

Det er også fra dette område, at de første kendte kontakter fra det kristne Vesteuropa til det hedenske Norden finder sted. Initiativet blev taget fra bispebyen Utrecht, hvorfra angelsachseren Willibrord (død 739) ved begyndelsen af 700-årene opsøgte danskernes konge Angantyr (Ongendeus).

Besøget hos danerkongen er skildret $\mathrm{i}$ Willibrords helgenlevned, hvis forfatter var en af de larde ved Karl den Stores hof i Aachen, angelsachseren Alkuin. Efter hans opfattelse hørte danskerne til de vilde folk, og Angantyr (Ongendeus) kalder han "grummere end noget vildt dyr og hårdere end nogen sten; alligevel behandlede han på Guds bud sandhedens forkynder med respekt $\ll$. Willibrord fik ovenikøbet lov til at tage 30 danske drenge med sig til dåbsundervisning i Utrecht, og det er muligvis i forbindelse med udfærdigelsen af denne skildring, at Alkuin i 789 beder en unavngiven abbed i sachsernes land hilse biskoppen af Bremen og underrette ham, »om der er noget håb om danskernes omvendelse? ${ }^{4}$

På den tid var Sigfred (Sigifridus) dansk konge, og ej heller han var velset hos frankerne. Man trøstede sig dog med, at han frygtede Karl 
den Store. »Thonar (Thor) og Wodan (Odin) kan ikke hjælpe ham mod dig «, hedder det i nogle vers, rettet til frankernes herre. ${ }^{5}$

I 772 var Karl trængt ind i sachsernes land for at underlægge sig denne den sidste af de tyske stammer, der ikke hørte ind under det kristne Frankerrige. Krigen blev meget langvarig, og en overgang, 777 til 782, havde en af sachsernes høvdinge, Widukind (Widochind), sammen med sine trofaste søgt tilflugt hos kong Sigfred, hos wnormannerne«, som det hedder i de Frankiske Rigsannaler. ${ }^{6}$

Da frankerne omsider i 804 havde afsluttet erobringen af Sachserlandet, var Godfred (Godofridus) dansk konge (»rex Danorum«), og for ham og hans folk var det alt andet end lyse udsigter at have fået det kristne Europa til nærmeste nabo. Utvivlsomt foruroliget af den nye situation samlede han i sommeren 804 »sin flåde og hele sit riges rytteri ved Sliesthorp på sit riges grænse ud mod sachsernes land (Saxonia)«, og han nægtede at møde til en forhandling med kejser Karl. I stedet kom et frankisk gesandtskab for at anmode om udlevering af »overløbere«, vel sagtens af sachsere, der havde søgt tilflugt i Danmark.

Nogle år senere, i 808, meddeles det i de Frankiske Rigsannaler, at Godfred havde gjort to tredjedele af abodriterne (der havde samarbejdet med frankerne) skatskyldige, og at en anden vendisk stamme, wiltzerne, af fri vilje havde sluttet sig til danskerne. Inden han forlod vendernes land, lod han en handelsplads (emporium) ødelægge ved havets kyst, der »i danskernes sprog" kaldes Reric. "Som skatskyldig under danskerne havde denne handelsplads hidtil bragt hans rige stor fordel; men nu førte han købmændene bort, lettede anker og kom med hele sin hær til den havn (portus), som hedder Sliesthorp. Her blev han i flere dage og besluttede at befæste sit riges grænse mod Sachsen med en vold (vallum), der strakte sig fra den østlige bugt af det hav, som de [danskerne] kalder Ostarsalt, og ud til det vestlige Ocean, således at der langs med hele Ejderens nordlige bred strakte sig et fæstningsværk, kun afbrudt af en eneste port (porta), gennem hvilken vogne og ryttere kunne komme ud og ind. Dette arbejde fordelte han mellem sine befalingsmænd og vendte derefter hjem. ( - Det er denne skildring i de Frankiske Rigsannaler, der er blevet klassisk som udgangspunkt for al drøftelse af problemerne omkring Danevirke. Samtidig har vi her det tidligste vidnesbyrd om, at kongemagten har haft indtægter af handel og købmandskab. 
Godfreds magtdemonstration førte ikke, som man kunne have ventet, til en krig med frankerne. Kejser Karl nøjedes med at sende sin søn af samme navn til Elben med et starkt opbud af frankere og sachsere og pålagde ham at gøre modstand mod "den vanvittige konge«, dersom han skulle forsøge et angreb på sachsisk område. Det skete imidlertid ikke. Frankerne gik i stedet over Elben og hærgede nogle landområder, der var beboet af et par vendiske stammer, linonerne og smeldingerne, der ligesom wiltzerne havde sluttet sig til danskerne; men derefter trak de sig atter tilbage.

I løbet af det følgende år blev det klart, at hverken frankerne eller danskerne ønskede krig. Tværtimod lod Godfred gennem nogle købmænd (negotiatores) sige, at han var villig til en forhandling. "Det var de andre, som først havde brudt aftalerne«, d.v.s. det var abodriterne, der under deres samarbejde med frankerne havde glemt deres skyldighed over for den danske konge! Godfred foreslog derfor et møde mellem frankiske og danske stormænd ved hans riges grænse whinsides « Elben, d.v.s. i Holsten. Dette møde fandt også sted, men forblev uden resultat. Parterne stod for langt fra hinanden.

Alligevel fik mødet en afgørende betydning. Det blev nemlig kejser Karl og hans frankere klart, at drømmen om Frankerrigets grænse langs med Elben og planen om at overlade den sachsisk beboede del af det nuværende Holsten til deres vendiske forbundsfæller, abodriterne, måtte opgives. ${ }^{7}$ Abodriterne var alt for svage til at kunne virke som et bolværk ved frankernes nordgrænse, og det blev derfor i 809 besluttet på grund af danskekongens overmod - at grundlægge en by med frankisk besætning hinsides Elben. Byen blev anlagt ved floden Stör, fik navnet Esesfelth (det nuværende Itzehoe) og blev den 15. marts 809 taget $\mathrm{i}$ besiddelse af den frankiske grev Egbert og af sachsiske grever, der nu samarbejdede med frankerne. At den frankiske plan fra 804 om en rømning af de nordelbiske sachseres bosættelsesområde i det nuværende Holsten blev opgivet, kan således i sidste ende tilskrives kong Godfred og hans overmod (superbia regis Danorum).

Mens kejser Karl i 810 opholdt sig i Aachen og planlagde et felttog mod kong Godfred, fik han melding om, at en flåde på 200 skibe fra "Nordmannia" havde gjort landgang i Frisland (Frisia). Alle de frisiske øer var blevet hærget, og den normanniske hær havde på fastlandet tilføjet friserne tre slag, og de sejrrige danskere havde pålagt de besejrede en tribut, hvoraf 100 pund sølv straks var blevet udbetalt.

Overraskelsen over dette angreb har åbenbart været stor hos franker- 
ne, for i Rigsannalerne hedder det efter ovennævnte omtale: $„ O \mathrm{Og}$ således var det virkeligt!«

Kejser Karl samlede omgående sine tropper; men inden de var nået frem til Wesers munding, fik han underretning om, at den flåde, der havde hærget frisernes land, var vendt tilbage, og at Godfred, der ikke personligt havde deltaget $i$ angrebet, var blevet myrdet af en af sine undergivne. "Efter danskekongen Godfreds død efterfulgte ham hans brodersøn Hemming (Hemmingus), og han sluttede fred med kejseren «, hedder det til sidst i Rigsannalernes beretning om begivenhederne i 810 .

Det følgende år meddeles, at freden på grund af den kolde vinter, der havde umuliggjort rejser, kun var blevet svoret "på våbnene«; men lige så snart de af den hårde frost lukkede veje var blevet farbare, mødtes tolv frankiske og tolv danske stormænd til et regulært fredsmøde et sted (navnet er ikke blevet indføjet) på den anden side af Ejderen. ${ }^{8}$ Mødets deltagere er nævnt med stor omhu og opført efter deres rang og betydning, og der kan derfor ikke være tvivl om, at Rigsannalernes forfatter har haft kendskab til den afsluttede traktat, der blev lovformeligt godkendt på en efterfølgende rigsdag i Aachen.

På frankisk side nævnes først kejserens søskendebarn, grev Wala, og blandt de øvrige navne genkendes grev Egbert, grundlæggeren af Esesfelth. Blandt de danske deltagere nævnes forst kong Hemmings brødre, Hancwin (Hakon?) og Angandeus (Angantyr). Tre af de navngivne hedder Osfred og har derfor tilnavne. Osfred fra Skåne (Osfrid de Sconaowe) er en af dem. ${ }^{9}$ Der nævnes også en "Suomi“, antagelig en fejllæsning for Gluomi (Glum), der nævnes i 817. Warstein og Urm (Gorm) er et par andre af stormændene, og sidst nævnes Hebbi (Ebbe) og Aowin (Ejvind?). De to bragte senere hen på året som kong Hemmings gesandter kejseren gaver og forsikring om fredens fortsatte beståen.

Men allerede året efter skete der atter noget uventet, idet kong Hemming døde, og to meldte sig straks til den ledige trone, Sigfred, en nevø af Godfred, og Anulus (Ale?), en nevø af en tidligere kong Harald (Heriold). Under de efterfølgende kampe mellem kongsemnerne faldt de begge, men Anulus' parti havde sejret, og det indsatte Harald (Herioldus) og Regnfred (Reginfrid) til konger. Kampene oplyses at have kostet 10.940 mænd; men den slags tal skal man naturligvis ikke tage for fuldt pålydende.

Endnu i 812 henvendte de to kongebrødre sig til frankerne med 
anmodning om at få den fred fornyet, som kong Hemming havde sluttet, samt om at få en tredje broder, Hemming, der opholdt sig hos frankerne, sendt hjem. Følgen blev et nyt fredsmøde i 813, denne gang med deltagelse af seksten på hver side, der dog ikke findes nævnt ved navn. Også dette møde fandt sted hinsides Elben ved normannernes grænse ("trans Albim ad confinia Normannorum«).

Mens mødet fandt sted, var de to kongebrødre med en hær draget til Vestfold ( Westarfolda «), »et landskab ved den yderste nordvestgrænse af deres rige, henimod nordspidsen af Britannien, hvis høvdinge og folk havde nægtet dem lydighed“. Næppe var de to konger vendt tilbage og havde modtaget deres broder Hemming, som kejseren havde sendt tilbage, før kong Godfreds sønner og wikke få af de danske stormænd «, der allerede i lang tid havde opholdt sig i eksil hos svenskerne, vendte tilbage med en hærstyrke og begyndte krig mod de frankervenlige konger. Fra alle egne af Danmark ("Danorum terra strømmede der nye skarer til, og efter en kamp tilrev de sig uden større anstrengelse herredømmet.

Efter Karl den Stores død i 814 forsøgte Harald og Regnfred igen at tilrive sig magten, men forgæves. Regnfred og Godfreds ældste søn fandt døden under denne kamp, og Harald søgte tilflugt hos frankernes nye kejser, Ludwig »den Fromme«.

Så snart foråret havde holdt sit indtog, sendte Ludwig i maj 815 en blandet frankisk-sachsisk-abodritisk hær af sted for at hjælpe Harald tilbage til kongemagten i Danmark. Hæren gik over Ejderen ind $i$ »det normanniske landskab Sinlendi« og lejrede sig den syvende dag ved havets kyst. Her blev den $i$ tre dage, men ved en $ø,{ }^{10}$ tre mil fra fastlandet, havde Godfreds sønner opbudt en stor hærmagt og en flåde på 200 skibe. Da danskerne ifølge Rigsannalerne ikke vovede at binde an med dem, nøjedes Ludwigs hær med at hærge i de omliggende egne og at tage fyrre gidsler, hvorefter den vendte tilbage til Sachsen.

I 817 sendte Godfreds sønner et gesandtskab til frankerne for at bede om fred. Årsagen hertil var de fortsatte angreb, som Harald påførte dem. Men Ludwig og hans mænd stolede ikke på deres ønske om fred og støttede derfor fortsat Harald. Det kom de snart til at fortryde, for nogen tid senere fik man ved hoffet i Aachen underretning om, at deres hidtidige forbundsfæller, abodriterne, var faldet fra. Deres konge havde sendt et gesandtskab nover havet" (trans mare) til Godfredsønnerne for at slutte venskab med dem, og det lykkedes dem at få danskerne til at angribe de nordelbiske sachsere. Danskernes flåde sejlede op ad Elben og ad Stör til den frankiske fæstning Esesfelth og 
hærgede hele egnen omkring Stör, det nuværende Stormarn. Samtidig drog også Glum (Gluomi) i egenskab af dansk grænsejarl (custos normannici limitis) med sit fodfolk og sammen med abodriterne mod fæstningen ved Stör, men som følge af frankernes "tapre modstand" måtte danskerne og deres hjælpere opgive angrebet.

I 819 meldes der atter om tronstridigheder hos danskerne. Baggrunden synes at være den, at det var lykkedes frankerne at genvinde deres magt over abodriterne, hvis konge var blevet ført til Aachen. Under disse forhold støttede Ludwig Haralds tilbagevenden, og to af Godfreds sønner søgte forbund med Harald for at dele magten med ham. Altimens havde to andre Godfred-sønner forladt deres land. Der var forræderi med i spillet, hedder det i Rigsannalerne.

Året efter er der en melding om, at tretten "sørøverskibe" (piraticae naves) først havde anløbet den flamske kyst, og da de her var blevet slået tilbage af kystvagten, gjorde de et nyt forsøg ved Seine-mundingen; men først ved den aquitanske (vestfranske) kyst havde de heldet med sig, plyndrede landsbyen Bouin og vendte hjem med rigt bytte.

I 821 herskede der fred hos danskerne, hvor Harald delte magten med Godfreds sønner, og året efter modtog Ludwig på en rigsdag i Frankfurt am Main gesandter fra en lang række folk, bl.a. også normanniske gesandter fra Harald og Godfreds sønner. En fredelig udvikling syntes herefter at kunne forudses, men i løbet af et års tid (823) blev det frankerne klart, at tilstandene i danskernes rige var alt andet end stabile. Harald kom fra »Nordmannia« for at klage sin nød, da Godfreds sønner havde fordrevet ham!

To frankiske gesandter, greverne Theothar og Rodmund, blev sendt til Godfreds sønner for at undersøge forholdene på selve åstedet. Ved hjemkomsten til Frankerriget gav de Ludwig en omhyggelig rapport over det normanniske riges tilstand, og ved samme lejlighed hjemførte de ærkebiskop Ebo af Reims, der havde opsøgt danskerne for at prædike evangeliet. Rapportens indhold kan vi kun ane; men der er næppe tvivl om, at den har gjort det klart, at frankerne skulle foretrække Harald som deres mand.

Midt på sommeren 826 havde kejser Ludwig taget ophold i Ingelheim, og hertil kom der også et gesandtskab fra Godfreds sønner, men da den landflygtige kong Harald (»Harald Klak «) lod sig døbe i den nærliggende domkirke i Mainz, blev det ham, frankerne satsede på. Ved at overlade ham lenet Rüstringen ved Wesers munding sikrede de ham et udgangspunkt for forsøgene på at genvinde magten i Danmark. På sin vej tilbage til sit hjemland, hvorfra han hurtigt atter blev 
fordrevet, havde Harald to munke med fra klosteret Korvey i Sachsen, Ansgar og Autbert. I et samvirke med kirkens mænd håbede frankerne på, at der ad åre kunne banes vej for en varig fredstilstand. Året 826 er derfor et vendepunkt $\mathrm{i}$ forbindelsen mellem frankerne og danskerne.

De Frankiske Rigsannalers årlige optegnelser handler om begivenheder inden for det store Frankerrige og om dettes forhold til de omboende folkeslag. Et af disse folk var danskerne - eller normannerne, som de lige så ofte kaldes. Det er derfor helt forkert at oversætte "normanner" med "nordmænd «. Der er klart tale om danskerne. Udviklingen hos dette folk følges på det nøjeste, og der lægges ikke skjul på, at danskerne omkring år 800 hørte blandt de større folk i datidens Europa. De få og spredte kilder fra tiden, før frankerne i 804 var nået frem til Elben, vidner om, at der allerede i 700-årene har eksisteret en stærk dansk kongemagt. Uden en sådan ville Danevirke-systemets to ældste byggeperioder i 737 og 808 også have været utænkelig.

I de perioder, hvor kongemagten var stærkest, har denne rimeligvis haft herredømmet over hele det danske folks bosættelsesområde, således som det kendes $i$ senere tider. Det var et rige, bestående af halvøer, øer og lange kyststrækninger, sammenknyttet af forbindelsen fra kyst til kyst. I Angantyrs, Sigfreds og Godfreds tid rakte dansk kongemagt sydpå til det øde grænseområde, der skilte dem fra sachserne. Navnet Osfred fra Skåne (811) vidner om, at også denne dansk befolkede landsdel hørte med til det danske rige.

Nord for Halland har danske konger udøvet et herredømme over området omkring Oslo-fjord. Det bevidnes af Rigsannalernes meddelelse om, at de to kongebrødre Harald og Regnfred i 813 var draget til Vestfold, landskabet vest for Oslo fjord, hvis »høvding og folk nægtede dem lydighed « og derfor måtte bringes til underkastelse. Vestfold oplyses at ligge ved »den yderste nordvestgrænse af de danske kongers rige, henimod nordspidsen af Britannien«, en tilføjelse, der utvivlsomt har skullet give Rigsannalernes læsere et begreb om det danske riges storhed og dermed en forklaring på, hvorfor Frankerrigets ledere foretrak forhandlinger frem for krig. ${ }^{11}$

Allerede tidligt havde danske kongers støtte til sachserne gjort det klart for frankerne, at det danske folk ikke kunne jævnstilles med de forskellige vendiske stammefolk, som de traf ved Elben. Godfreds ankomst til Sli-området i 804 kan kun opfattes som en art mobilisering 
af de danske styrker, og formålet har været at forklare frankerne: "hertil og ikke længere! «

På samme måde med begivenhederne i 808. Godfred anså ikke mere handelspladsen med det danske navn Reric for at være sikker, hverken for dens købmænd eller som indtægtskilde for kongemagten. Han lod derfor købmændene flytte til Sliesthorp, åbenbart en handelsplads, der i forvejen var kendt af frankerne. I Sliesthorps nærhed lod han Danevirke-volden udbygge, således at den sikrede den livsvigtige handelsforbindelse tværs over den Jyske Halvøs rod.

Abodriterne fik ved samme lejlighed en alvorlig advarsel; to tredjedele af dem måtte finde sig $i$ at betale en tribut, og andre vendiske stammer - wiltzerne, linonerne og smeldingerne - anerkendte frivilligt dansk overhøjhed. I forbindelse med frankernes fremrykning mod Elben havde abodriterne glemt deres tidligere forpligtelser over for den danske konge. „Det var de andre, der først havde brudt aftalerne!« forklarede Godfred frankerne som grund til angrebet på abodriterne.

Det blev hurtigt klart, at frankerne havde afskrevet deres hidtidige forbundsfæller, abodriterne, og som nævnt er der næppe tvivl om, at Godfred med sit angreb har reddet de nordelbiske sachseres bosættelsesområder, Ditmarsken, Holsten og Stormarn, fra at blive et vendisk område. En art væbnet fred prægede i de næste par år forholdet mellem frankerne og danskerne. Godfred havde i 808 påbegyndt udbygningen af Danevirke, og frankerne sikrede altimens deres nordflanke ved anlægget af Esesfelth i de nordelbiske sachseres land.

På Godfreds foranledning kom der i 809 en forhandling i stand nord for Elben mellem frankere og danskere; men mødets resultat blev negativt. Parterne stod for langt fra hinanden, og man planlagde derfor i Aachen et angreb på danskerne; men Godfred og hans mænd kom først. Det danske angreb gjaldt friserne og deres øer på handelsruten langs med Nordsøens kyst.

Helt siden Hugleiks togt i 515 havde denne kyst været udsat for spredte angreb af danskerne, og man tør derfor antage, at friserne har betalt tribut til den danske konge for at slippe for fjendtligheder. Måske er det sådanne formentlige rettigheder, Godfreds udsendinge havde nævnt over for de frankiske forhandlere i 809. Vi ved det ikke, men Einhart, frankernes historieskriver, nævner under omtalen af Godfreds overmod, at han anså ikke blot Frisland, men også Sachsen for at være sine 


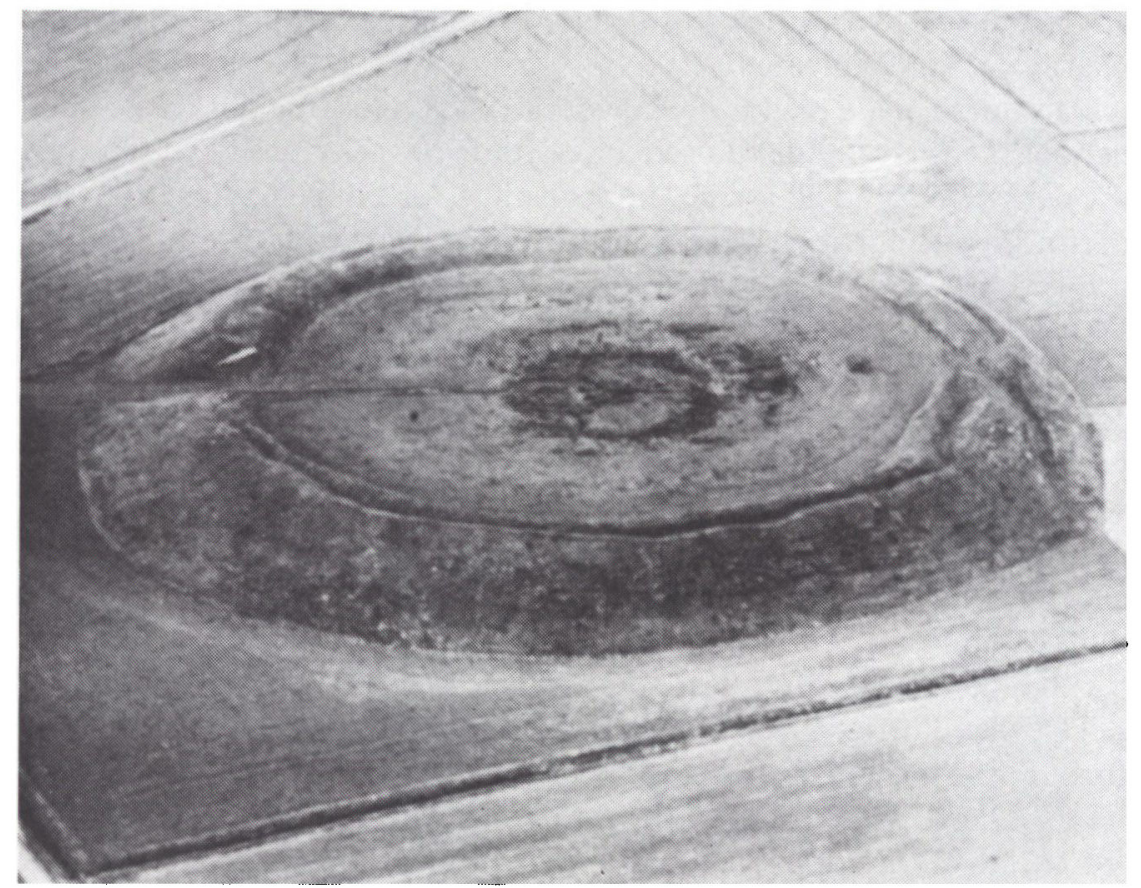

Luftbillede af Lembeksburg på Føhr (Efter Peter La Baume: Was wissen wir über die Lembecksburg auf Föhr?)

provinser. Abodriterne havde han allerede lagt ind under sit herredømme, og nu truede han med at komme til Aachen med sin hær! Kun hans pludselige død i 810 gjorde ende på hans formastelige planer. ${ }^{12}$

Godfreds optræden på Friserkysten skal naturligvis sammenholdes med de samtidige beretninger om vikingetog vestpå, men sådanne nævnes overhovedet ikke i de Frankiske Rigsannaler, når der ses bort fra meldingen om de tretten "piratskibes« strandhugst i 820. Men netop denne notits viser, at vikingerne blev slået $\mathrm{i}$ hartkorn med sørøvere, der handlede på egen hånd. Der var med andre ord ikke tale om et politisk anliggende mellem frankere og danskere. En handling af offentlig politisk natur, værdig til omtale i Rigsannalerne, var derimod Karl den Stores inspektion af den "galliske« kyst i marts 800 . Dette område var gjort usikkert af »sørøvere« (pirati), og Karl lod derfor her en flåde bygge og en vagttjeneste indrette. Kun ad denne indirekte vej hører vi i Rigsannalerne om de igangværende vikingetog.

Det er den Angelsachsiske Krønike, der giver de første meldinger om 


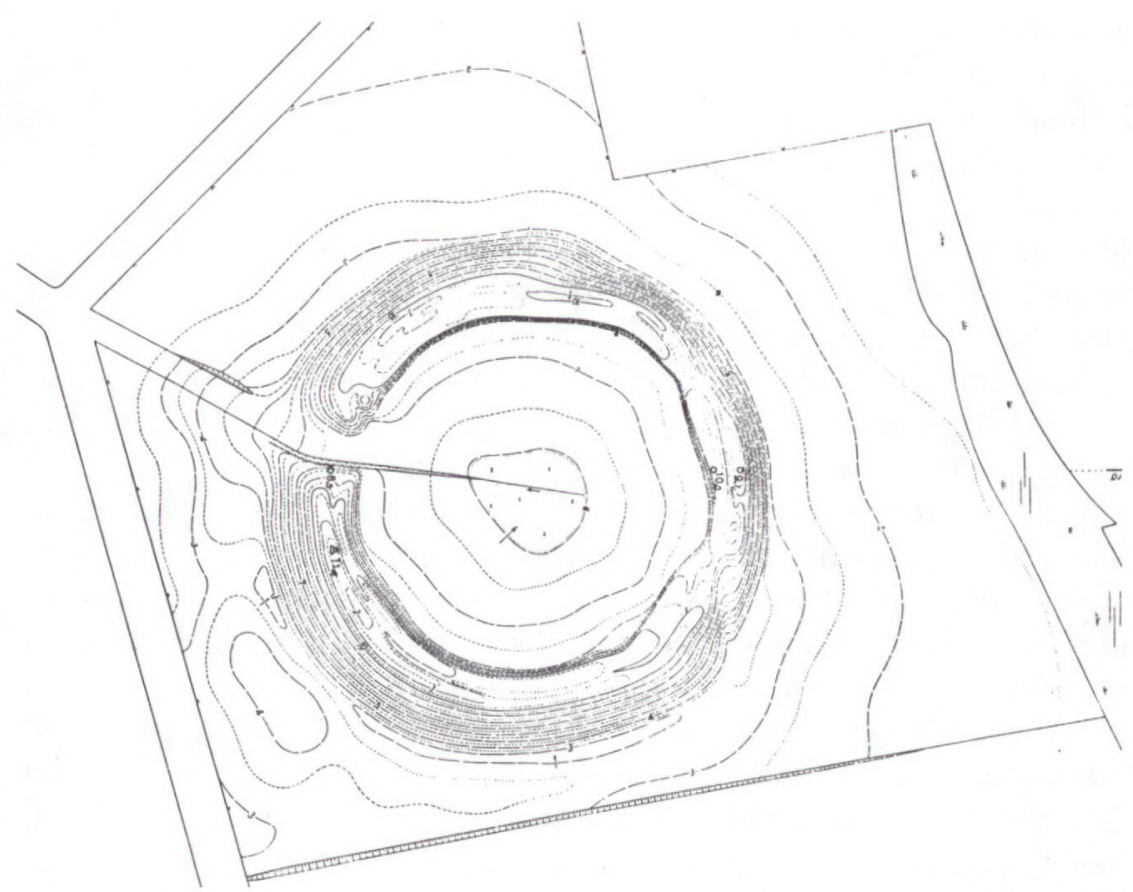

Plantegning af Lembeksburg, 1:5000 (Landesvermessungsamt i Kiel, efter Peter La Baume: Grabhügel und Burgen auf Amrum und Föhr)

vikingeangreb, nemlig fra 789 om tre skibe med normanner, der var gået $\mathrm{i}$ land ved Portland på Englands sydkyst. En stedlig greve ville føre dem til kongen af Wessex, men de dræbte ham. ${ }^{13}$ "Disse var de første skibe med danske mænd, som gjorde landgang i England «, og den næste omtale af et vikingeangreb er derefter den almindeligt kendte plyndring af klosteret Lindisfarne i det nordøstlige England.

I det bevarede brevstof nævnes i 792 »omstrejfende flåder«, der fører hedningerne til kysten af Kent i det sydøstlige England, og efter overfaldet på Lindisfarne sender angelsachseren Alkuin fra sit ophold ved hoffet $\mathrm{i}$ Aachen trøstende ord til sine landsmænd $\mathrm{i}$ anledning af det, der var hændt. »Betænk, at $\mathrm{i}$ næsten 350 år har vi og vore forfædre boet i dette såre smukke land, og aldrig tidligere er en så rædselsfuld gerning forekommet i Britannien som den, vi nu har været udsat for fra et hedensk folks side; ej heller havde man troet, at et sådant søtogt kunne forekomme.« Nogle år senere advarer Alkuin sine landsmænd mod indbyrdes splid: "Nu truer en stor fare denne $ø$ og folket, som bor på 
den. Betænk - hvad man aldrig før har hørt -, at et hedensk folk har fået for vane at plyndre vore kyster og øve strandhugst«. Ved århundredskiftet giver samme brevskriver ærkebiskoppen af Salzburg en rystende skildring af, hvad der foregik ude ved Oceanets kyst: "Hedninge har udrettet meget ondt på øerne i Oceanet ved Akvitanien (det nuværende Vestfrankrig). En del af dem omkom dog; der blev på stranden dræbt henved 105 af disse røvere. Deres anfald er en stor prøvelse for det kristne folk, helt ukendt i tidligere tider«.

Med omtalen af vikingeangreb også på den vestfranske kyst ved år 800 , må Rigsannalernes notits om et angreb i 820 anses for en enkelt af flere episoder af den art. Forholdene blev efterhånden så vanskelige, at klosteret Noirmoutier måtte flyttes. Tilladelsen hertil blev givet den 16 . marts 819 og blev begrundet med barbarernes angreb, »hvilke hyppigt hærger dette kloster«. I 830 nævnes det, at munkene, der trods tilladelsen til flytning alligevel opholdt sig i Noirmoutier, var tvunget til at forlade det »fra forårets begyndelse til slutningen af efteråret «. ${ }^{14}$

Vikingeskibenes jævnlige tilsynekomst - efterhånden år efter år - ved Noirmoutier, ved Bouin og andre »akvitanske« lokaliteter ved Baie-deBourgneuf, som middelalderen igennem har givet navn til Baie-saltet, kan næppe være tilfældig. Det må på baggrund af saltets enestående betydning i ældre tiders handelsliv være rimeligt at pege på, at det er saltet herfra - fra det nordligste sted ved Europas kyst, hvor havsalt lod sig udvinde ved at udnytte solvarmens naturlige fordampningsevne -, der har været den vare, som har ført folket fra det salthungrende Norden så langt af led. ${ }^{15}$

Samme vare - omend af ringere kvalitet - lod sig også inden for frisernes egne bosættelsesområder udvinde af tørv fra Vadehavets moser, og dette frisiske salt har helt naturligt dannet grundlag for den handel, der tillægges dette folk, og som naturligvis udviklede sig til at omfatte mange andre varegrupper. ${ }^{16}$ Set på denne baggrund har det ikke været en barbarkonges tilfældige lune eller vanvittige overmod, der førte til, at kong Godfred lod sin store flåde på 200 skibe angribe frisernes kyst og tvinge dem til at betale tribut.

Årene efter Godfreds død i 810 er opfyldt af ustandselige kampe mellem danske kongsemner. Det foreløbige resultat af disse kampe blev, at Godfreds sønner blev vraget til fordel for hans nevø Hemming, der gik ind for fred med frankerne, og samme kurs fulgte efter Hemmings død de to kongebrødre, Harald og Regnfred. 
De to fredsmøder, der i 811 og 813 blev en følge af denne kurs, viser, at de var tilrettelagt $i$ henhold til de regler, der galder mellem ligeberettigede folk og deres regeringsmagt. Det er for det første tilfældet med mødestedernes placering. Lokaliteterne er desværre ikke oplyst, men mødet i 811 synes at have fundet sted på dansk grund, måske fordi det resultatløse møde i 809 var blevet afholdt på frankisk grund. Mødet i 813 blev afholdt på et egnet sted så nær ved grænsen som muligt. Ligeberettigelsen kommer endvidere til udtryk gennem deltagerantallet, i 811 tolv fra hver side, i 813 seksten fra hver side. Og navnene, der kendes på mødets deltagere i 811, understreger ydermere den betydning, som de to folks ledere tillagde fredsslutningen.

Men hos danskerne sejrede det anti-frankiske parti, da det i 814 lykkedes Godfreds sønner at tilrive sig magten. Den frankervenlige kurs havde åbenbart ikke været populær, for fra alle egne af Danmark strømmede der nye skarer til, som støttede Godfred-sønnerne.

For hoffet i Aachen var det nye regime i Danmark en stor skuffelse, og næppe havde Karl den Store lukket sine øjne for stedse, før hans søn og efterfølger Ludwig besluttede sig for krig. En hær blev i 815 sendt ind over grænsen og op i Sønderjylland (Sinlendi). ${ }^{17}$ Om kampe ved Danevirke meldes der ikke noget. Den syvende dag lejrede hæren sig ved havets (oceanets) kyst, og her blev den i tre dage, men ude ved en $\sigma$ lå en dansk flåde på 200 skibe. Nu indrømmer Rigsannalerne naturligvis ikke, at frankerne havde travlt med at komme tilbage til deres enemærker. Det var danskerne, der ikke turde binde an med dem, hedder det, og frankerne foretog derfor »et taktisk tilbagetog«, hærgede i de omkringliggende egne og tog gidsler med hjem.

Situationen kan kun forstås, dersom det var ved Nordsø-kysten, at den danske flåde lå, og betegnelsen »oceanet« peger da også på Nordsøen. Oceanet var hos frankerne almindeligvis navnet på havet vest, nordvest og nord for Frankerriget, lige fra Pyrenæerne til Ejderen, d.v.s. Atlanterhavet, Kanalen og Nordsøen, mens de to indhave, Middelhavet og Østersøen, i datidens latinske skriftsprog kaldtes "mare ${ }^{18}$ Hvis det har været ved Nordsøen, at frankerne har opdaget den danske flåde, har det været farligt for dem, for ved at gå op i Elbmundingen ville danskerne være $i$ stand til at afskære dem fra et tilbagetog. Atter og atter oplevede man i netop disse år, at vikingerne sejlede op ad de store flodmundinger.

Kun en sådan, strategisk set farlig situation kan have tvunget frankerne til et omgående tilbagetog. Hvor ærefuldt det end skildres i Rigsannalerne, betød det en rømning af handelscentret ved Haddeby 
Nor og en opgivelse af kontrollen med den for danskerne så livsvigtige forbindelse tværs over den Jyske Halvøs rod.

De begivenheder, der fandt sted i 817, bekræfter rigtigheden af denne opfattelse. Denne gang var det danskerne, der angreb, og hensigten har antagelig været at få frankerne fordrevet fra de nordelbiske sachseres land. Den store flåde gik op ad Elben og ad Stör og spærrede for den søværts forbindelse til den frankiske fæstning Esesfelth, og altimens lagde grænsejarlen Glum sig med en hærstyrke foran Esesfelth. Der var således tale om en velgennemtænkt militær planlægning, ganske på samme måde som Godfreds overflytning af Rerics købmænd til Sliesthorp og hans fordeling af arbejdet med voldbyggeriet mellem befalingsmændene er et udtryk for danskernes organisatoriske færdigheder.

Det lykkedes frankerne at afvise angrebet; men det stod dem klart, at et nyt indfald over Ejderen ville være uigennemførligt. Dertil var danskerne for stærke. Fremtiden lå $i$ et samarbejde med de kredse $i$ Danmark, der var villige til et sådant, og da en splid mellem Godfredsønnerne atter bragte Harald frem i søgelyset, måtte det være ham, man skulle satse på. Ved sin dåb i Ingelheim i 826 blev han Frankerrigets vasal i Danmark, men tabte i indflydelse i sit hjemland. Der skulle gå lange tider hen, før der var skabt et godt og varigt naboforhold. Men skildringen heraf falder uden for denne afhandlings rammer.

Den store danske flåde, der vides at have opereret i Nordsøen i 810 og igen i 817 , samt sandsynligvis også i 815 , må et eller andet sted på kysten have haft både havn og forsyningsbase, og her kommer de nordfrisiske geest-øer, Sild, Amrum og Føhr, helt naturligt ind i billedet.

Blandt de mange fortidsminder, som disse øer rummer, ${ }^{19} \mathrm{er}$ der i den her givne forbindelse særlig grund til at pege på de to største blandt flere ringvolde, nemlig den såkaldte Lembeksburg ved Borgsum på Føhr og den store ringborg ved Tinnum på Sild. Størst indtryk på den besøgende gør den velbevarede Lembeksburg, hvis ringvold med en højde af 11 meter og med en fodbredde på henved 25 meter omslutter et kredsrundt areal, hvis diameter er på 100 meter. Tinnumburg, der vel tidligere har ligget ud til havet, er ikke helt rund. Dens diameter er ca. $120 \times 100$ meter. De fund, der er gjort, daterer begge borge til begyndelsen af 800-tallet. 
Almindeligvis bliver de to voldanlæg ligesom andre ældre og mindre anlæg på øerne af lignende art $^{20}$ opfattet som tilflugtsborge for befolkningen i urostider. Udgravningerne af de danske "Trelleborge" førte ganske vist tanken hen på, om de nordfrisiske ringvolde også var militære anlæg, skabt af den danske kongemagt, men denne opfattelse blev forladt ud fra den begrundelse, at både Lembeksburg og Tinnumburg var betydeligt ældre end de danske Trelleborge. ${ }^{21}$ I stedet er de frisiske ringvolde blevet sammenholdt med de store anlæg af lignende art, som f.eks. kendes på øen Walcheren ved Souburg og ved Middelburg. At der også på de kanter har været perioder, hvor danske vikinger havde herredømmet, synes $\mathrm{i}$ den forbindelse almindeligvis upåagtet.

Atter og atter var Walcheren i begyndelsen af 800 -årene målet for vikingeangreb, atter og atter må friserne betale tribut, ja i 846 hedder det, at danske pirater var landet i Frisland, og efter at have afkrævet tribut havde de »bemægtiget sig næsten hele landet . $^{22}$ Mon de store ringvolde her derfor også skulle være vikingernes værk?

Det er ikke her opgaven at gennemgå de mange spredte notitser om vikingernes tilstedeværelse på Friserkysten og langs med Nordsøens kystrute helt ud til Noirmoutier og andre havnepladser i det nuværende Vestfrankrig, men det har været hensigten med nærværende afhandling at henlede opmærksomheden på, at den danske kongemagt allerede ved år 800 hørte blandt de mest anselige i Europa, en kendsgerning, som man bør have $\mathrm{i}$ tankerne også ved kommende tiders arkæologiske undersøgelser. Det må nemlig være indlysende, at så vældige ingeniørarbejder som anlægget af Danevirke og af de store ringvolde på de Nordfrisiske Øer kun har været mulige, når betydelige ressourcer har stået til rådighed, og fra slutningen af 700-årene og begyndelsen af 800årene havde alene den danske kongemagt sådanne ressourcer til rådighed.

\section{NOTER}

1. Der henvises generelt til de litteraturfortegnelser, der findes udarbejdet $i$ : Aksel $E$. Christensen: Vikingetidens Danmark, 1969, 1977, s. 278-291; Gyldendals Danmarks Historie, I, 1977 (v. Inge Skovgaard-Petersen), s. 145-147; Else Roesdahl: Danmarks Vikingetid, 1980, s. 297-318. Endv. H. V. Gregersen: Det begyndte for Lindisfarne (Festskrift til Troels Fink, 1982, s. 29-51).

2. Norge (»Nordvejen«, Nuruiak på Jelling-stenen), samt Halland og Blekinge er $i$ deres geografiske udstrækning vidnesbyrd om gamle tiders kystsejlads.

3. Jvf. H. V. Clausen: Studier over Danmarks Oldtidsbebyggelse (Aarbøger for nordisk 
Oldkyndighed, 1916). Se iøvrigt kort over -lev-byernes udbredelsesområde, f.eks.: Peter Skautrup: Det danske Sprogs Historie, I, 1944, s. 28; H. V. Gregersen: Slesvig og Holsten indtil 1830, 1981, s. 31.

4. Diplomatarium Danicum (Danmarks Riges Breve), 1. rk., I, nr. 1.

5. Jvf. Curt Weibull: De đanske och skånska vikingatågen till Västeuropa under 800talet (Scandia 1977, 43, 1), spec. s. 52-53, med henvisning til Monumenta Germania historica; Poetæ latinæ ævi Carolini, I, s. 50.

6. Citaterne fra de Frankiske Rigsannaler er taget fra den latinsk/tyske Freiherr vom Stein-Gedächtnisausgabe, bd. V (Quellen zur Karolingischen Reichsgeschichte, I); ved at følge årstallene vil bevisstedet nemt kunne findes.

7. "Han gav de transelbiske egne til abodriterne«, hedder det 804 i de Frankiske Rigsannaler. En folkeflytning af de nordelbiske sachsere i Ditmarsken, Holsten og Stormarn blev ikke gennemført, men udgravningerne 1949-51 af det før-frankiske Hamburg har vist, at der en kort tid har været en vendisk besætning her. Jvf. Arno Jenkis: Die Eingliederung "Nordalbingiens" in das Frankenreich (Zeitschrift der Gesellschaft für Schleswig-Holsteinische Geschichte, 1955, 79, s. 81-104).

8. Jvf. Lauritz Weibull: Fredsfördragen mellan frankerna och danerna 811 och 813 (Scandia 1940, bd. 13, s. 141-150).

9. Da Skåne således uomtvisteligt var en del af det danske rige, er titlen på Curt Weibulls afhandling i Scandia 1977, »De danska och skånska vikingatågen etc. « lidt af en misforståelse, historisk set!!

10. Danske historikere, lige fra Johs. Steenstrup til Aksel E. Christensen, har formodet, at den unavngivne ø måtte være Fyn, se: Danmarks Riges Historie, I, s. 217 (Johs. C. H. R. Steenstrup) wvistnok Fyen«; Aksel E. Christensen: Vikingetidens Danmark, s. 133, »antagelig Fyn«.

11. Omtalen af Britannien kan $i$ forbindelse med de igangværende vikingetog også være en antydning af, at det var fra det norske område, at vikingerne var sejlet tværs over havet til Lindisfarne og andre lokaliteter i Storbritannien. Måske har de to danske konger ønsket at skaffe sig kontrol over denne sejlads, der, efter at skibene var blevet mere sødygtige, gjorde nordmændene uafhængige af forbindelsen over Danmark. Inden udviklingen inden for skibsbygningskunsten gik vejen fra Norge til Vesteuropa nemlig via de danske farvande og over den Jyske Halvøs rod ud af Ejder-mundingen. Den kystnære sejlads findes endnu omkring 890 bevidnet i Ottars skildring af rejseruten fra Norge til Slesvig/Hedeby.

12. Einhart, der også er oversat til dansk, findes sammen med Rigsannalerne i Freiherr vom Stein-Gedächtnisausgabe, jvf. note 6.

13. Den angelsachsiske udgave har $i$ modsatning til den ældre latinske, at de pågældende vikingers hjemsted var »Hæredeland $«$. Denne oplysning formodes dog at være en senere interpolation, jvf. Aksel E. Christensen: Vikingetidens Danmark, s. 125.

14. Diplomatarium Danicum/Danmarks Riges Breve, 1. rk., I, nr. 2, 9, 12, 15, 20, 24.

15. Med hensyn til salthandel kan der generelt henvises til litteraturoversigten i: Erik Hellerup Madsen: Salt og salthandel i østersøområdet $\mathrm{i}$ tidlig middelalder (Hikuin, VI, s. 293-294).

16. Jvf. Dirk Jellema: Frisian Trade in the dark ages (Speculum. A Journal of Medieval Studies, nr. 30) Massachusetts, Cambridge 1955, s. 15-36; Poul Enemark: Om problemer vedrørende friserhandelen (Jyske Samlinger, ny rk., V, 2, 1960, s. 121163); Aksel E. Christensen: Birka uden frisere (Handels- og Søfartsmuseets Årbog, 1966, s. 17-37). 
17. Betydningen af "Sinlendi«, i King Alfred's Orosius (udg. H. Sweet, I, 1883, s. 16, 19) kaldt "Sillende«, er uklar, men i begge tilfælde må der være tale om et ældre navn for Sønderjylland. Diskussionen om betydningen af dette navn er refereret i Peter Jørgensen: Über die Herkunft der Nordfriesen, 1946, s. 38-39.

Vilh. Marstrand har i sit oldhistoriske værk fra 1933, "Aabenraa« (som handler om alt muligt andet) også beskæftiget sig med »Sillende«, og s. 40 i nævnte værk giver han denne forklaring: "Navnet er i nutiden bevaret $\mathrm{i}$ onavnet Sild, der tidligere skreves Siland, Seland, men maa oprindelig have betegnet et langt større omraade巛. I samme værk gør han opmærksom på, at navnet også forekommer hos Adam af Bremen, hvor det om biskop Odinkar af Ribe oplyses, at han var søn af Toke, jarl af Winland. "Han var jarl af Sinland, som Adams text skal læses, ikke Vinland, der ingen mening giver« ("Aabenraa", s. 41). Det skal tilføjes, at Inge SkovgaardPetersen i Gyldendals Danmarks Historie, I, s. 109, har forsøgt sig med en omskrivning til "Sli-land (jvf. Paul G. Buchloh i Offa, bd. 37, 1980, s. 364: »Schleiland(). Heroverfor forekommer Vilh. Marstrands tolkningsforsøg nok så rimeligt.

18. En gennemgang af Rigsannalerne og af Einharts historieværk viser dette tydeligt. Mest kendt er nok omtalen af Godfreds Danevirke-vold i 808: "... vallo munire constituit, eo modo, ut ab orientali maris sinu, quem illi Ostarsalt dicunt, usque af occidentalem oceanum ...« Der er kun fundet een undtagelse: Reric siges at ligge »in oceani litorex! Under omtalen af kystvagtens indrettelse ved oceanet forekommer ordet »mare« én gang, men utvivlsomt kun af sproglige grunde, fordi ordet woceanus « ellers ville blive for ofte gentaget.

19. Jvf. Karl Kersten \& Peter La Baume: Vorgeschichte der nordfriesischen Inseln, 1958 (Lembeksburg: s. 231-235; Tinnumburg: s. 583-585).

20. F.eks. Archsumburg, jvf. Georg Kossack \& Ole Harck: Grabungen in der Archsumburg auf Sylt (Germania, 1973, bd. 51, s. 478 ff.); Georg Kossack, Ole Harck \& Joachim Reichstein: Zehn Jahre Siedlungsforschung in Archsum auf Sylt, 1975.

21. Herbert Jankuhn: Ein Burgentyp der späten Wikingerzeit in Nordfriesland und sein historischer Hintergrund (Zeitschrift der Gesellschaft für Schleswig-Holsteinische Geschichte, 1954, bd. 78, s. 1-21): »Es ergab sich für die Forschung die alternative Fragestellung: Fluchtburg der einheimischen Bevölkerung gegen die die Küstengebiete beunruhigenden Wikinger - oder Stützpunkt einer wikingischen Heeresabteilung als Operationsbasis für Vorstösze in die westlichen und südlichen Küstengebiete der Nordsee. Diese Frage konnte - wenn überhaupt - dann nur durch Ausgrabungen geklärt werden ... Für eine Beantwortung der Frage nach einem möglichen Zusammenhang zwischen der Lembecksburg und der dänischen Trelleborg ... ist die Altersbestimmung von entscheidender Bedeutung«.

22. En fortegnelse over »vikingernes angreb og militære foretagender på det vest- og sydeuropæiske fastland $\mathrm{i}$ det 9 . århundrede«, samt over »tributter og gaver nævnt $\mathrm{i}$ de oversatte tekster«, findes i Erling Albrectsen: Vikingerne i Franken, 1981, s. 135-143. 
